\title{
Integrated Lecture Tools to Improve Student Competencies to Develop Physical Learning Media Design
}

\author{
I Made Astra ${ }^{1, a)}$, Upik Rahma Fitri ${ }^{2, b)}$ \\ ${ }^{1}$ Program Studi Pendidikan Fisika FMIPA Universitas Negeri Jakarta \\ ${ }^{2}$ Laboratorium Pengembangan Media Pembelajaran Fisika, FMIPA Universitas Negeri Jakarta

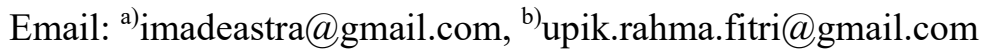

\begin{abstract}
Have been developed a lecture tool for Physics Learning Media Development course. Development applies the ASSURE model, with activities: analysis stages, formulating objectives, selecting media, selecting course materials, developing lecturing tools, implementations to collect student responses, and evaluations. The tools consist of syllabus, hand out, Student Activity Sheet, and Student Performance Appraisal Sheet. This research product has been tested on Physics Education Student of FMIPA UNJ. Student's response to lectures was collected using a fourteen-item questionnaire. The average score given by the students to the lecture is 72.03 good category. Student Performance Making Learning Media Design using this research product average 77,95 good category. Based on the student's response and the student's performance score in making the design of physics learning media, it can be concluded that the integrated lecture tools developed are worthy to be used as teaching materials for the Context Based Learning Media Learning course.
\end{abstract}

Keywords: Lecture tools, Media design, Media development.

\begin{abstract}
Abstrak
Telah dikembangkan perangkat perkuliahan untuk mata kuliah Pengembangan Media Pembelajaran Fisika. Pengembangan menerapkan penelitian pengembangan yang mengacu pada model ASSURE, dengan tahapan analisis kebutuhan, merumuskan tujuan, memilih media, memilih materi perkuliahan, menyusun perangkat perkuliahan, implementasi untuk mengumpulkan respon mahasiswa, dan evaluasi. Perangkat perkuliahan yang dikembangkan terdiri dari silabus, hand out, Lembar Kegiatan Mahasiswa, dan Lembar Penilaian Kinerja Mahasiswa. Produk penelitian ini sudah diujicobakan terhadap mahasiswa Pendidikan Fisika FMIPA UNJ. Respon mahasiswa terhadap perangkat perkuliahan dijaring menggunakan angket yang terdiri dari empat belas butir. Rerata skor yang diberikan mahasiswa terhadap perangkat perkuliahan adalah 72,03 kategori baik. Kinerja mahasiswa Membuat Desain Media Pembelajaran menggunakan produk penelitian ini rerata 77,95 kategori baik. Berdasarkan respon mahasiswa dan nilai kinerja mahasiswa dalam membuat desain media pembelajaran fisika, dapat disimpulkan bahwa perangkat perkuliahan terintegrasi yang dikembangkan layak digunakan sebagai bahan ajar untuk mata kuliah Pengembangan Media Pembelajaran Fisika Berbasis Konteks.
\end{abstract}

Kata-kata Kunci: Perangkat perkuliahan, Desain media, Pengembangan media. 


\section{PENDAHULUAN}

Terdapat tiga hal mendasar penyelesaian masalah pendidikan melalui penerapan metode ilmiah; yaitu penelitian (research), evaluasi (evaluation) dan pengembangan (development). Gephart (1972: 3) menjelaskan tentang tiga hal tersebut bahwa proses penelitian tujuannya untuk menemukan/mengetahui tentang kebutuhan (need to know), proses evaluasi bertujuan untuk menentukan pilihan (need to choose), dan proses pengembangan bertujuan untuk menemukan suatu cara/metode yang effektif (need to do).

Borg and Gall (1983) memberikan batasan tentang penelitian pengembangan sebagai usaha untuk mengembangkan dan memvalidasi produk-produk yang digunakan dalam pendidikan. Pengertian yang hampir sama dikemukakan oleh Asim (2001: 1) bahwa penelitian pengembangan dalam pembelajaran adalah proses yang digunakan untuk mengembangkan dan memvalidasi produk-produk yang digunakan dalam proses pembelajaran. Suhadi Ibnu (2001: 5) memberikan pengertian tentang penelitian pengembangan sebagai jenis penelitian yang ditujukan untuk menghasilkan suatu produk hard-ware atau soft-ware melalui prosedur yang khas yang biasanya diawali dengan need assesment, atau analisis kebutuhan, dilanjutkan dengan proses pengembangan dan diakhiri dengan evaluasi.

berdasarkan pendapat para ahli tersebut, dapat diartikan bahwa penelitian pengembangan di bidang pendidikan merupakan suatu jenis penelitian yang bertujuan untuk menghasilkan produkproduk untuk kepentingan pendidikan/pembelajaran yang diawali dengan analisis kebutuhan dilanjutkan dengan pengembangan produk, kemudian produk dievaluasi diakhiri dengan revisi dan penyebaran produk (disseminasi). Pada peneliitian ini penelitian pengembangan diaplikasikan untuk meningasah kompetensi mahasiswa mengembangkan media pembelajaran fisika.

Media pembelajaran dibutuhkan sebagai media yang menjadi penghubung antara sumber dengan penerima informasi dalam proses pembelajaran. Kehadiran media pembelajaran sebagai perantara antara guru sebagai pengirim informasi dan siswa sebagai penerima informasi harus komunikatif, khususnya untuk obyek secara visualisasi. Dalam pembelajaran ilmu pengetahuan alam, khusunya konsep yang berkaitan dengan alam semesta lebih banyak menonjolkan visualnya, sehingga apabila seseorang hanya mengetahui kata yang mewakili suatu obyek, tetapi tidak mengetahui obyeknya disebut verbalisme. Masing-masing media mempunyai keistimewaan menurut karakteristik siswa. Pemilihan media yang sesuai dengan karakteristik siswa akan lebih membantu keberhasilan pengajar dalam pembelajaran.

Dalam melaksanakan tugasnya, guru (pengajar) diharapkan dapat menggunakan alat atau bahan pendukung proses pembelajaran, dari alat yang sederhana sampai alat yang canggih (sesuai dengan perkembangan dan tuntutan jaman). Bahkan mungkin lebih dari itu, guru diharapkan mampu mengembangkan keterampilan membuat media pembelajarannya sendiri. Oleh karena itu, guru (pengajar) harus memiliki pengetahuan dan pemahaman yang cukup tentang media pembelajaran, yang meliputi (Hamalik, 1994): (i) media sebagai alat komunikasi agar lebih mengefektifkan proses belajar mengajar; (ii) fungsi media dalam rangka mencapai tujuan pendidikan; (iii) hubugan antara metode mengajar dengan media yang digunakan; (iv) nilai atau manfaat media dalam pengajaran; (v) pemilihan dan penggunaan media pembelajaran; (vi) berbagai jenis alat dan teknik media pembelajaran; dan (vii) usaha inovasi dalam pengadaan media pembelajaran.

Menurut Gerlach dan Ely (dalam Arsyad,2002:11) ciri media pendidikan yang layak digunakan dalam pembelajaran adalah sebagai berikut:

a) Fiksatif (fixative property)

Media pembelajaran mempunyai kemampuan untuk merekam, menyimpan, melestarikan, dan merekonstruksi suatu peristiwa/objek.

b) Manipulatif (manipulatif property)

Kejadian yang memakan waktu berhari-hari dapat disajikan kepada siswa dalam waktu dua atau tiga menit dengan teknik pengambilan gambar time-lapse recording.

c) Distributif (distributive property)

Memungkinkan berbagai objek ditransportasikan melalui suatu tampilan yang terintegrasi dan secara bersamaan objek dapat menggambarkan kondisi yang sama pada siswa dengan stimulus pengalaman yang relatif sama tentang kejadian itu. 
Keterlibatan siswa dalam kegiatan belajar mengajar sangat penting, karena seperti yang dikemukakan oleh Edgar Dale (dalam Sadiman, dkk, 2003:7-8) dalam klasifikasi pengalaman menurut tingkat dari yang paling konkrit ke yang paling abstrak, dimana partisipasi, observasi, dan pengalaman langsung memberikan pengaruh yang sangat besar terhadap pengalaman belajar yang diterima siswa. Penyampaian suatu konsep pada siswa akan tersampaikan dengan baik jika konsep tersebut mengharuskan siswa terlibat langsung didalamnya bila dibandingkan dengan konsep yang hanya melibatkan siswa untuk mengamati saja. Kajian psikologi menyatakan bahwa anak akan lebih mudah mempelajari hal yang konkrit ketimbang yang abstrak. Jenjang konkrit-abstrak ini ditunjukkan dengan bagan dalam bentuk kerucut pengalaman (cone of experiment), seperti yang ditunjukkan pada GAMBAR 1.

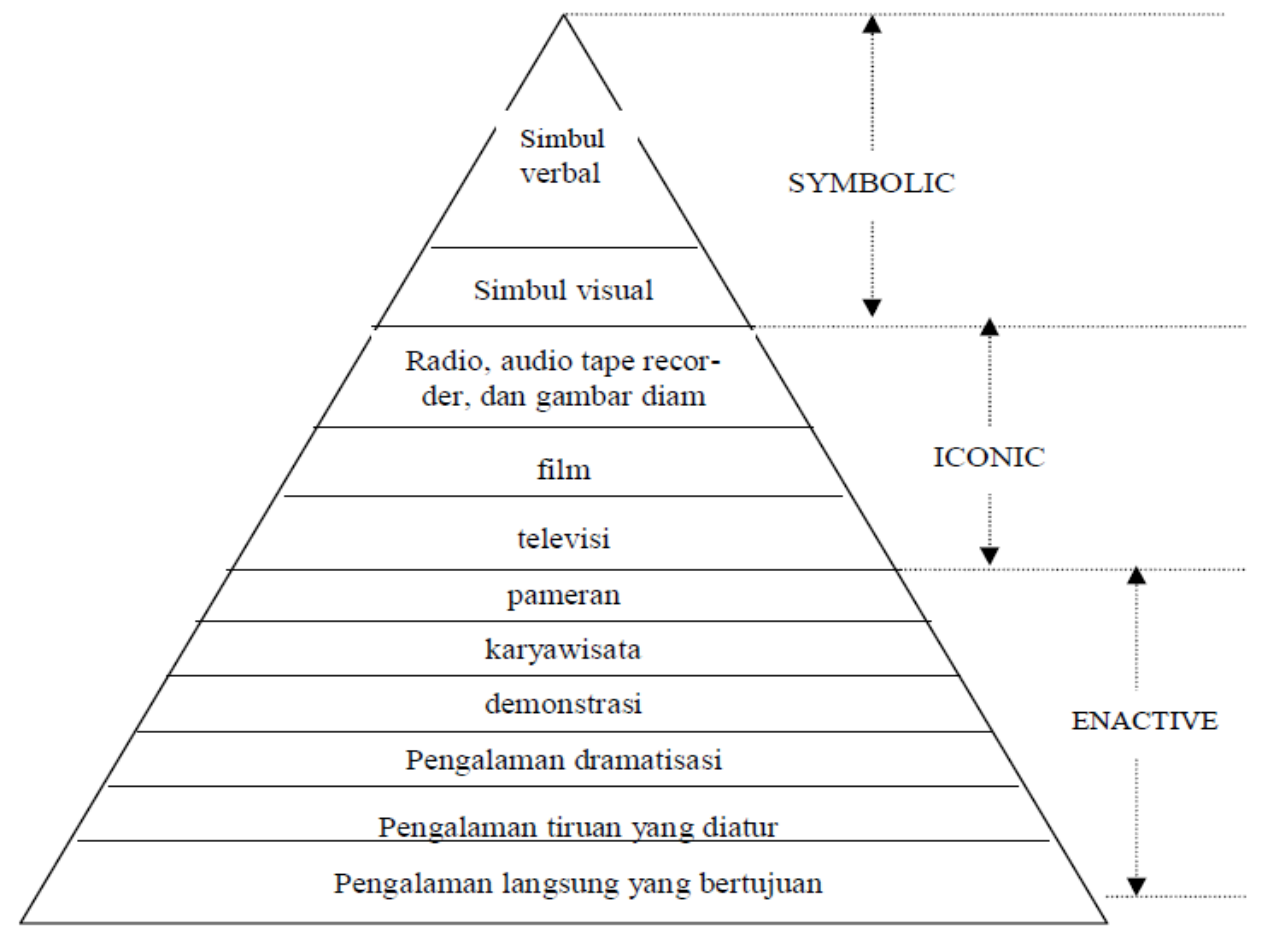

GAMBAR 1. Kerucut pengalaman Dale (Heinich, et.al., 2002).

Fungsi pedagogik media pembeajaran yang dimaksud tidak mungkin diwujudkan tanpa penggunaaan media pembelajaran yang tepat. Proses pembelajaran merupakan proses komunikasi dan berlangsung dalam suatu sistem, maka media pembelajaran menempati posisi yang cukup penting sebagai salah satu komponen sistem pembelajaran. Tanpa media, komunikasi tidak akan terjadi dan proses pembelajaran sebagai proses komunikasi juga tidak akan bisa berlangsung secara optimal. Media pembelajaran adalah komponen integral dari sistem pembelajaran. Posisi media pembelajaran sebagai komponen komunikasi ditunjukkan seperti pada GAMBAR. 2

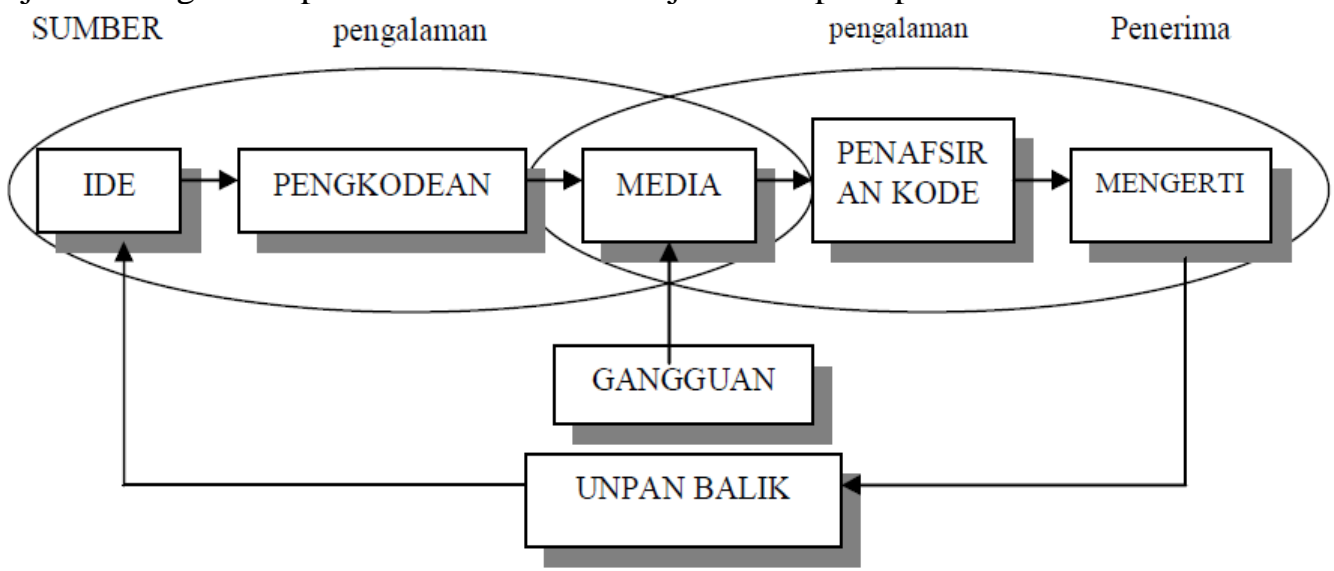

GAMBAR 2. Posisi Media dalam Sistem Pembelajaran. 
Dalam proses pembelajaran, media memiliki fungsi sebagai pembawa informasi dari sumber (guru) menuju penerima (siswa). Sedangkan metode adalah prosedur untuk membantu siswa dalam menerima dan mengolah informasi guna mencapai tujuan pembelajaran. Fungsi media dalam proses pembelajaran ditunjukkan pada GAMBAR 3.

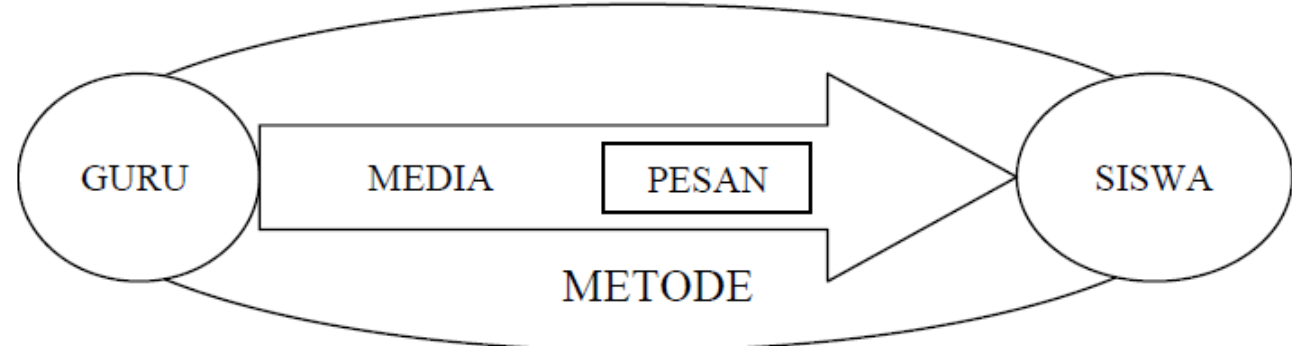

GAMBAR 3. Fungsi media dalam proses pembelajaran.

Dalam kegiatan interaksi antara siswa dengan lingkungan, fungsi media dapat diketahui berdasarkan adanya kelebihan media dan hambatan yang mungkin timbul dalam proses pembelajaran. Tiga kelebihan kemampuan media (Gerlach \& Ely dalam Ibrahim, et.al., 2001) adalah sebagai berikut. Pertama, kemapuan fiksatif, artinya dapat menangkap, menyimpan, dan menampilkan kembali suatu obyek atau kejadian. Dengan kemampuan ini, obyek atau kejadian dapat digambar, dipotret, direkam, difilmkan, kemudian dapat disimpan dan pada saat diperlukan dapat ditunjukkan dan diamati kembali seperti kejadian aslinya. Kedua, kemampuan manipulatif, artinya media dapat menampilkan kembali obyek atau kejadian dengan berbagai macam perubahan (manipulasi) sesuai keperluan, misalnya diubah ukurannya, kecepatannya, warnanya, serta dapat pula diulang-ulang penyajiannya. Ketiga, kemampuan distributif, artinya media mampu menjangkau audien yang besar jumlahnya dalam satu kali penyajian secara serempak, misalnya siaran TV atau Radio.

Proses pembelajaran pada hakikatnya merupakan proses komunikasi, yaitu proses penyampaian suatu pesan. Komunikasi dapat terjadi jika komponen-komponennya terpenuhi. Komponen proses komunikasi terdiri atas pesan, sumber pesan, media perantara, dan penerima pesan (Yanto, 2011).

Terkait dengan komponen media sebagai perantara dalam proses pembelajaran, guru atau calon guru tidak cukup menguasai kompetensi menggunakana media pembelajaran saja. Lebih dari sekadar menggunakan media, guru juga harus mampu memilih, merancang, dan mengembangkan media pembelajaran.

Keterampilan pengembangan media pembelajaran didukung oleh teori tentang media pembelajaran, karakteristik materi ajar, tingkat berpikir peserta didik, serta penerapan metode ilmiah dalam proses pengembangan. Keterampilan mengembangan media pembelajaran fisika, butuh pengalaman. Dalam rangka melatih keterampilan mahasiswa mengembangan media pembelajaran ini, dibutuhkan pengalaman belajar riel seperti layaknya pekerjaan guru dalam mengembangkan media pembelajaran, sebagai bagian tugasnya.

Perlu bahan ajar untuk menuntun mahasiswa berlatih menerapkan keterampilan mengembangkan media pembelajaran secara mandiri. Bahan ajar dikembangkan dengan mengintegrasikan seluruh kompetensi melalui pendekatan ilmiah untuk melatih keterampilan berpikir kreatif. Pengintegrasian kompetensi yang meliputi kompetensi sikap, keterampilan dan pengetahuan, dilakukan pada setiap bahasan materi (Mufida, 2014). Atas dasar pemikiran di atas, tim peneliti dari Program Studi Pendidikan Fisika melakukan penelitian, guna memberikan pengalaman belajar kepadaa mahasiswa dalam menerapkan metode ilmiah untuk mengembangkan media pembelajaran fisika. Untuk mencapi maksud tersebut dikembangkanlah perangkat perkuliahan terintegrasi. Dengan perangkat perkuliahan ini mahasiswa pendidikan fisika dipandu melakukan pengembangan media pembelajaran fisika dan mengukur secara mandiri kemampuannya.

Salah satu sub kompetensi pedagogik yang harus dikuasai oleh calon guru adalah memilih dan mengembangkan media pembelajaran. Pengembangan kompetensi profesional dan pedagogik dilakukan dengan memberikan kesempatan bagi para guru dalam meningkatkan pengetahuan dan keterampilan mereka untuk mengembangkan bahan pengajaran dan menggunakan berbagai metode pembelajaran di proses pembelajaran, memberi kesempatan bagi para guru untuk berinisiatif dan 
kreatif dalam berkarya untuk mengembangkan pengetahuan wawasan (Azzet, 2011). Peningkatan motivasi guru cenderung rendah karena fasilitas dan kurangnya media pembelajaran. Peningkatan motivasi harus didukung oleh prinsipal untuk memberikan kesempatan bagi para guru untuk melakukan penelitian dan melakukan berbagai kegiatan yang bertujuan meningkatkan aktivitas guru (Mulyasa, 2007).

Pentingnya kemampuan memilih dan mengembangkan media pembelajaran sebagai alat bantu yang memudahkan guru melatih keterampilan proses sains siswa. Kemahiran proses sains adalah asas kepada pembelajaran berasaskan inkuiri. Pembelajaran sains melibatkan penguasaan kemahiran proses sains dan penggunaan dalam ujikaji saintifik (Tan, 2009). Keterampilan proses sains pada dasarnya terjadi secara alami pada diri manusia dengan spontan dalam pikiran. Manusia menggunakan keterampilan proses sains untuk mencari tahu jawaban terhadap semua pertanyaan tentang bagaimana dunia bekerja. Keterampilan proses sains tidak hanya berguna dalam sains, tetapi juga dalam situasi yang membutuhkan pemikiran kritis (Vitti \& Torres, 2006). Dengan menempatkan siswa sebagai pusat pembelajaran (student centered), keterampilan proses sains akan terintegrasi melalui tindakan-tindakan mereka. Guru tidak perlu menjelaskan kepada siswa setiap proses yang mereka alami karena siswa akan mencari tahu melalui proses penyelidikan yang memadukan beberapa keterampilan proses sains (Yager, 1996).

Calon guru harus memahami jenis-jenis media, prinsip pemilihan media, dan langkah pemilihan media. Kehadiran media pembelajaran sebagai media antara guru sebagai pengirim informasi dan penerima informasi harus komunikatif, khususnya untuk obyek secara visualisasi. Dalam pembelajaran ilmu pengetahuan alam, khusunya konsep yang berkaitan dengan alam semesta lebih banyak menonjol visualnya, sehingga apabila seseorang hanya mengetahui kata yang mewakili suatu obyek, tetapi tidak mengetahui obyeknya disebut verbalisme.

Masing-masing media mempunyai keistimewaan menurut karakteristik siswa. Pemilihan media yang sesuai dengan karakteristik siswa akan lebih membantu keberhasilan pengajar dalam pembelajaran. Dalam melaksanakan tugasnya, guru (pengajar) diharapkan dapat menggunakan alat atau bahan pendukung proses pembelajaran, dari alat yang sederhana sampai alat yang canggih (sesuai dengan perkembangan dan tuntutan jaman).

AECT (Association For Education Communication and Technology) 1979 mengklasifikasikan jenis sumber belajar menjadi 6 yaitu:

1. Pesan (message), yaitu informasi yang ditransmisikan (diteruskan) oleh komponen lain dalam bentuk ide, fakta, arti dan data. Termasuk ke dalam kelompok pesan adalah semua bidang studi, materi pokok atau mata kuliah yang harus diberikan pelayanan kepada para pengguna PSB.

2. Orang (people), yaitu manusia yang bertindak sebagai penyimpan, pengolah, penyaji pesan. Dalam kelompok ini jika dilihat dari sisi internal dimasukan para staff Pusat Sumber Belajar itu sendiri yang ada pada struktur organisasi PSB, yaitu:Kepala Sekolah, Koordinator PSB, Tenaga Adminitrasi, Ketua unit pengembangan sistem pembelajaran, Ketua unit pelayanan, dan Ketua unit pengembangan media. Selain para staff PSB itu sendiri juga, siswa/mahasiswa, guru/dosen/intruktur dan tenaga kependidikan termasuk kedalam sumber belajar itu.

3. Bahan (materials), yaitu perangkat lunak yang mengandung pesan untuk disajikan melalui penggunaan alat ataupun oleh dirinya sendiri. Berbagai program media termasuk kategori bahan terdiri dari 2 kriteria, yaitu material sederhana dan material mutakhir, misalnya tranparansi, slide, film, audio, video, modul, majalah, dan lain-Iain.

4. Alat (devices), yaitu perangkat keras yang digunakan untuk penyampaian pesan yang tersimpan dalam bahan. Misalnya, proyektor slide, overhead, video tape, pesawat televisi,

5. Teknik (techniques), yaitu prosedur atau acuan yang disiapkan untuk menggunakan bahan, peralatan, orang dan lingkungan untuk menyampaikan pesan. Contohnya pembelajaran terprogram, belajar sendiri, demonstrasi, ceramah, dan Iain-Iain

6. Lingkungan (setting), yaitu situasi sekitar di mana pesan disampaikan, lingkungan bisa bersifat fisik (gedung sekolah, perpustakaan, laboratorium, studio, dan sebagainya) maupun lingkungan non fisik (suasana belajar dan Iain-Iain). (Badru, 2007) 
Guna melatih kemampuan mahasiswa memilih dan mengembangkan media pembelajaran fisika, sekaligus keterampilan proses sains, dibutuhkan pengalaman belajar. Pengalaman belajar mengintegrasikan menjadi enam roposisi yakni:

1. Pembelajaran paling baik dipahami sebagai sebuah proses, bukan dalam hal hasil. Meningkatkan belajar di pendidikan tinggi, fokus utama harus melibatkan siswa dalam proses pembelajaran;

2. Semua belajar dengan belajar ulang. Belajar paling baik difasilitasi oleh sebuah proses yang menarik.

3. Belajar membutuhkan resolusi konflik antara mode yang berlawanan secara teori dengan yang terjadi dalam kehidupan nyata. Konflik, perbedaan, dan ketidaksepakatan inilah yang mendorong proses pembelajaran. Dalam proses belajar seseorang dipanggil untuk bergerak maju mundur

4. Belajar adalah proses holistik adaptasi. Hal ini bukan hanya hasil kognisi, tetapi melibatkan fungsi terpadu dari total orang-berpikir, merasakan, dan berperilaku. Ini mencakup model adaptasi khusus lainnya dari ilmiah. Metode pemecahan masalah, pengambilan keputusan dan berkreativitas.

5. Hasil belajar dari transaksi sinergis antara orang dengan lingkungan Hidup. Pola belajar manusia yang stabil dan abadi timbul dari sikap konsisten antara individu dan lingkungannya.

6. Belajar adalah proses menciptakan pengetahuan. Pengalaman belajar mengusulkan sebuah konstruktivis dimana pengetahuan sosial diciptakan dan diciptakan kembali dalam pribadi.

\section{METODE PENELITIAN}

Penelitian ini mengacu pada model penelitian pengembangan ASSURE, dengan tahapan analisis kebutuhan, merumuskan tujuan, memilih media, memilih materi perkuliahan, menyusun perangkat perkuliahan, implementasi untuk mengumpulkan respon mahasiswa, dan evaluasi. Dilakukan pada Program Studi Pendidikan Fisika FMIPA Universitas Negeri Jakarta pada tahun 2016. Validasi sejawat dilakaukan oleh teman sejawat pada program studi Pendidikan Fisika FMIPA UNJ, yang difokuskan pada silabus mata kuliah. Ujicoba dilakukan terhadap mahasiswa Pendidikan Fisika yang terdaftar sebagai peserta mata kuliah Pengembangan Media Pembelajaran Fisika pada semester ganjil 2017/2018. Respon mahasiswa terhadap Hand out, Lembar Kerja mahasiswa, dan Lembar Penilaian Kinerja Mahasiswa dijaring menggunakan questioner yang terdiri dari 14 butir. Sedangkan efektivitas hasil pengembangan sebagai bahan ajar diukur melalui kinerja mahasiswa menyusun desian pengembangan media dan mengembangan media pembelajaran.

\section{HASIL DAN PEMBAHASAN}

\section{Hasil Penelitian}

Penelitian ini menghasilkan produk berupa perangkat perkuliahan terintegrasi untuk mata kuliah Ketrampilan Mengajar pada Program Studi Pendidikan Fisika. Rincian produk yang dihasilkan disajikan pada TABEL 1 .

TABEL 1. Produk Penelitian

\begin{tabular}{lllll}
\hline No & Jenis Produk & Materi & $\begin{array}{l}\text { Pengembangan Media } \\
\text { Pembelajaran }\end{array}$ \\
\cline { 3 - 5 } & Srosedur Pembuatan & $\begin{array}{l}\text { Studi } \\
\text { Pedia Pembelajaran }\end{array}$ & Sendahuluan & $\sqrt{ }$ \\
\hline 2 & Hand Out & $\sqrt{ }$ & $\sqrt{ }$ & $\sqrt{ }$ \\
\hline 3 & $\begin{array}{l}\text { Lembar Kegiatan } \\
\text { Mahasiswa }\end{array}$ & $\sqrt{ }$ & $\sqrt{ }$ & $\sqrt{ }$ \\
\hline 4 & $\begin{array}{l}\text { Lembar Penilaian } \\
\text { Kinerja Mahasiswa }\end{array}$ & $\sqrt{ }$ & & \\
\hline
\end{tabular}




\section{Validasi Sejawat}

Tim peneliti sudah melakukan validasi semua produk penelitian. Dimana divalidasi dan diujicoba terbatas terhadap mahasiswa pendidikan fisika yang terdiri dari 26 orang. Validasi dilakukan dengan teman sejawat pada Program Studi Pendidikan Fisika FMIPA Universitas Negeri Jakarta. Data validasi sejawat berupa data kualitatif. Data dikumpulkan dengan teknik penelitian kualitatif, dengan melakukan diskusi intensif beberapa kali, termasuk di dalamnya diskusi saat workshop kurikulum. kegiatan, masukan, dan produk penelitian yang dihasilkan dan direvisi berdasarkan masukan teman sejawat, secara singkat disajikan pada TABEL 2.

TABEL 2. Tabel Data Validasi Sejawat

\begin{tabular}{|c|c|c|}
\hline Topik Bahasan & Masukan Sejawat & Produk \\
\hline $\begin{array}{l}\text { Silabus Mata Kuliah } \\
\text { Pengembangan Media } \\
\text { Berbasis Konteks. }\end{array}$ & $\begin{array}{l}\text { Sebaiknya jelas dan tegaskan batasan isi, } \\
\text { strategi, penugasan, dan produk mata } \\
\text { kuliah, sehingga tidak terjadi overlapping } \\
\text { dengan mata kuliah lain. }\end{array}$ & $\begin{array}{l}\text { Silabus mata kuliah Pengembangan } \\
\text { Media Berbasis Konteks. }\end{array}$ \\
\hline RPS & $\begin{array}{l}\text { Sebaiknya disesuaikan antara SKS mata } \\
\text { kuliah dengan tagihan, projek, produk, dan } \\
\text { strategi pencapaiannya. Disaranakan } \\
\text { perkuliahan lebih banyak menganalisis dan } \\
\text { mengkaji, serta membuat produk. }\end{array}$ & $\begin{array}{l}\text { RPS mata kuliah Pengembangan } \\
\text { Media Berbasis Konteks. RPS tidak } \\
\text { termasuk dalam produk yang } \\
\text { direncanakan di dalam penelitian ini. } \\
\text { Sehingga hanya dilakukan validasi, } \\
\text { tapi belum diujicoba. Karena } \\
\text { keterbatasan dana penelitian. }\end{array}$ \\
\hline
\end{tabular}

\section{Ujicoba Produk}

Produk penelitian telah diujicobakan terhadap mahasiswa Pendidikan Fisika yang terdiri dari 26 orang mahasiswa. Produk yang diujicoba terhadap mahasiswa adalah hand out, Lembar Kegiatan Mahasiswa, Dan Lembar Penilaian Kinerja Mahasiswa untuk materi Prosedur Pembuatan Media Pembelajaran, Studi Pendahuluan, dan Pengembangan Media Pembelajaran.

Data hasil ujicoba berupa (1) penilaian mahasiswa terhadap perangkat perkuliahan yang diujicobakan, yang dikumpulkan menggunakan angket, mencakup tiga aspek, yaitu materi/ isi, penyajian, dan bahasa, yang terdiri dari empatbelas butir, dengan empat kategori penilaian 1, 2, 4, dan 5; (2) kemampuan kinerja mahasiswa dalam mata kuliah Pengembangan Media Pembelajaran Berbasis Konteks, yang diukur menggunakan Lembar penilian Kinerja Mahasiswa. Dalam skala 1100 , skor nilai yang diberikan mahasisa terhadap produk penelitian ini, terendah 71,54, nilai tertinggi 83,08 , dengan rerata 77,57.

Penilaian yang diberikan mahasiswa terhadap terhadap produk penelitian ini, tergambar dari nilai yang diberikan terhadap empat belas butir angket, disajikan pada GAMBAR 4.

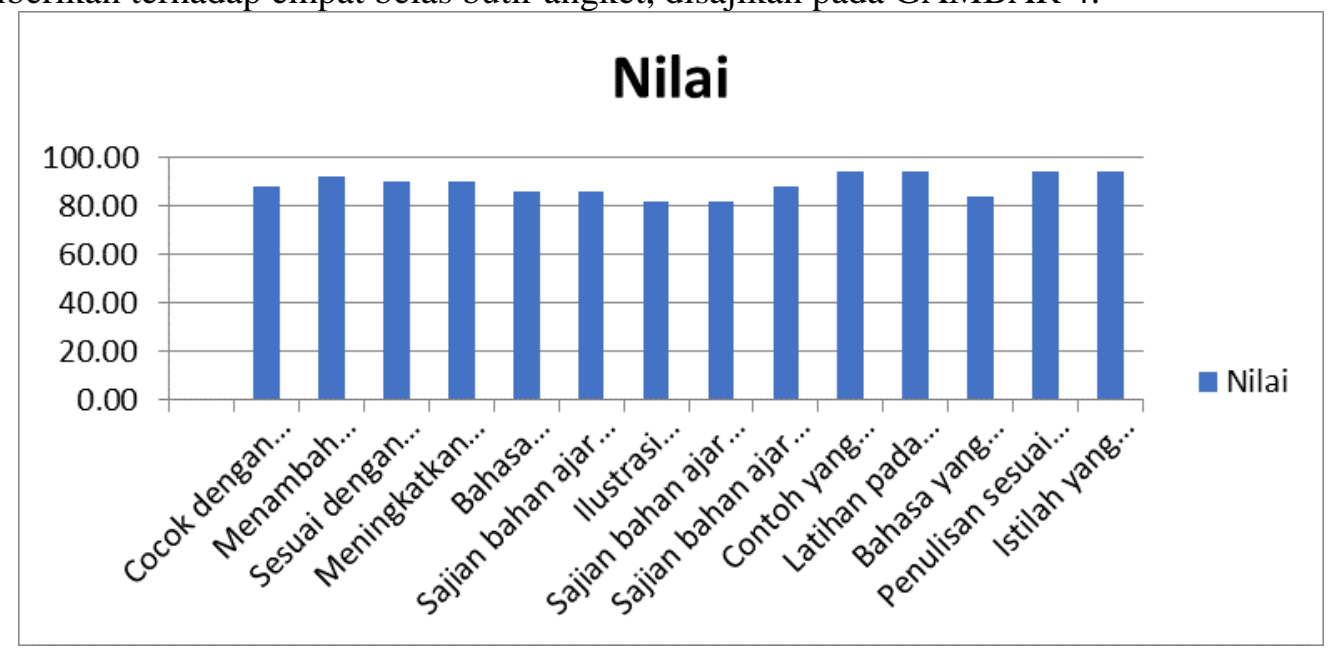

GAMBAR 4. Penilaian Mahasiswa Terhadap Produk Penelitian. 
Adapun distribusis data hasil penilaian mahasiswa tersebut, disajikan pada GAMBAR 5.

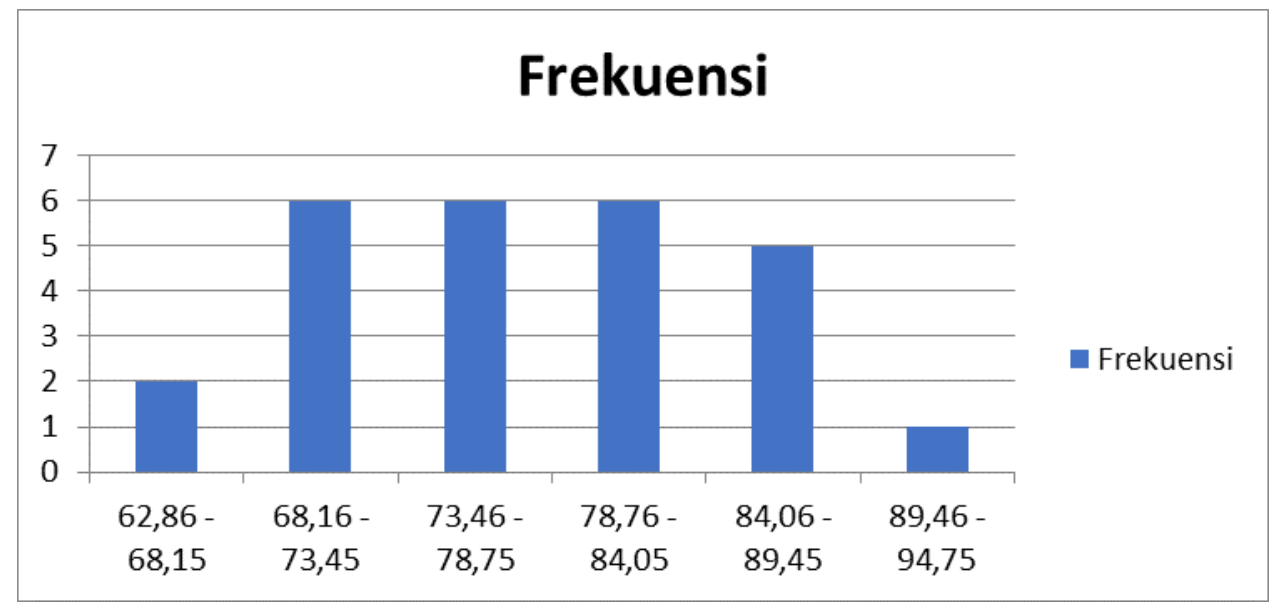

GAMBAR 5. Tabel Distribusi frekuensi penilaian mahasiswa terhadap produk penelitian.

Hasil penilaian kinerja mahasiswa untuk tiga materi perkuliahan Pengembangan Media Pembelajaran Berbasis Kontek, dapat dibaca pada GAMBAR 6.

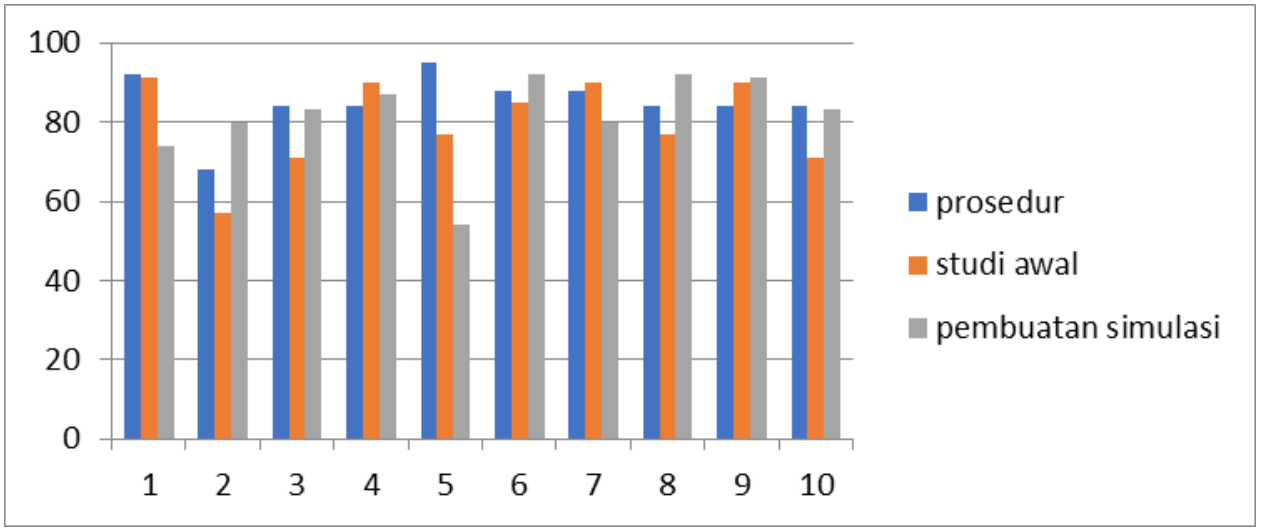

GAMBAR 6. Kinerja mahasiswa menggunakan produk penelitian.

Untuk materi pertama, prosedur pengembangan media nilai terendah 68, nilai tertinggi 95 , dan rerata 85,1. Sedangkan untuk materi kedua, studi pendahuluan mahasiswa memperoleh nilai terendah 57, nilai tertinggi 91, dan rerata 79,90; adapun untuk materi ketiga, pengembangan media pembelajaran fisika nilai mahasiswa dari 54 sampai 92 dengan rerata 81,6. Rerata kinerja mahasiswa untuk materi 1 dan 3 berada pada level sangat baik, sedangkan untuk materi ke 2 berada pada level baik.

\section{Pembahasan}

Produk penelitiai ini berupa perangkat mata kuliah yang terdiri dari silabus, Hand out, Lembar kegiatan Mahasiswa, dan Lembar Penilaian Kinerja Mahaiswa untuk Mata Kuliah Pengembangan Media Pembelajaran Fisika Berbasis Konteks. Pembuatan produk dimulai dengan diskusi intensif tentang mata kuliah Pengembangan Media Pembelajaran Fisika Berbasis Konteks. Kajian mendalam yang dilakukan terhadap pemasalahan penelitian ini dilakukan dalam rangka meminta masukan dari tim dosen kelompok mata kuliah Dasar Kependidikan Program Studi Pendidikan Fisika FMIPA UNJ. Telah dilakukan beberapa kali diskusi oleh tim MKDK pendidikan fisika. Diskusi dimulai dengan mengkaji KKNI Pendidikan fisika yang direkomendasikan oleh Asosiasi Program Studi Pendidikan Fisika Indonesia. Dimana KKNI tersebut disusun berdasarkan ketrampilan mengajar abad 21.

Informasi dan semua masukan sejawat yang berhasil kami serap kami jadikan sebagai masukan atau rujukan dalam mengembangkan semua produk penelitian ini. Sehingga cakupan materi, strategi, 
tagihan/ penugasan, dan produk mata kuliah sudah mendapatkan masukan dan mempertimbangan keterpenuhan kompetensi dan menghindari overlapping antar mata kuliah dalam kelompok MKDK.

Masukan dari teman sejawat berupa catata yang berbentuk data kualitatif, yang dikumpulkan dari hasil catatan pada saat diskusi intensif untuk silabus dan RPS mata kuliah Pengembangan Media Pembelajaran Fisika. Masukan yang diberikan oleh teman sejawat sangat bermanfaat dalam menghasilkan perangat perkuliahan yang baik dan bermanfaat bagi mahasiswa dalam mencapai kompetensi. Karena diskusi dengan teman sejawat terjadi sebelum pembuatan perangkat perkuliahan, pada saat, dan setelah draf perangkat tersebut disusun. Sehingga produk yang diujicobakan kepada mahasiswa sudah merupakan perangkat hasil validasi sejawat.

Hand out, Lembar Kerja Mahasiswa, dan Lembar Penilaian Kinerja Mahasiswa sebagai bahan ajar yang dikembangkan di dalam mata kuliah ini merupakan bahan ajar mandiri, saling bersinergi mengarahkan dan menuntun mahasiswa menggali pengetahuan tentang pengembangan media pembelajaran fisika, berlatih mengembangkan media pembelajaran, dan berlatih menilaian kinerja secara mandiri dan kolaboratif.

Perangkat perkuliahan Pengembangan Media Pembelajaran Berbasis Konteks yang dikembangkan ini memberikan tuntunan kepada mahasiswa tentang aktivitas belajar yang harus dilakaukan untuk mencapai kompetensi, target dari setiap aktivitas belajar, dan menentukan kapan waktunya bekerjasama dengan teman sejawat dan kapan pula saatnya harus bekerja menyelesaikan tugas sendiri tanpa bantuan teman. Mahasiswa juga diberikan arah atau petunjuk untuk bisa menilai kinerja dalam perkuliahan menggunakan lembar penilaian kinerja mahasiswa. Sedhingga tidak cukup alasan bagi mahasiswa untuk gagal mencapai kompetensi, apabila mereka menggunakan perangkat perkuliahan ini sesuai petunjuk penguunaannya.

Penggunaan perangat kuliah hasil pengembangan ini dalam perkuliahan. Memberikan pengalaman yang mirip dengan pekerjaan yang mesti dilakukan oleh seorang guru fisika SMA. Secara garis besar aktivitas belajar mahasiswa mencakup (1) membaca hand out, (2) mengerjakan latihan yang terdapat pada Lembar Kegiatan Mahasiswa 1, 2, dan 3 secara berurutan dalam kelompok kecil; (3) mengerjakan latihan personal yang terdapat di dalam Lembar Penilaian Kinerja 1, 2, dan 3 secara berurutan, dan (4) melakukan penilaian secara mandiri menggunakan lembar penilaian kinerja. Dimana penilaian kinerja ini dapata dilakukan langsung oleh mahasiswa bersangkutan dan dapat juga dilakaukan oleh teman sejawat mereka.

Kategori penilaian sangat baik yang diberikan oleh mahasiswa terhadap perangkat perkuliahan yang digunakan, tidaklah berlebihan. Karena respon mahasiswa terhadap produk penelitian ini dan kinerja mahasiswa menggambarkan sutu konsistensi. Respon mahasiswa sangat baik dan kinerja mereka juga sangat baik.

Peneliti yakin kalau mahasiswa telah memberikan respon yang objektif, karena sebelum menggunakan perangkat perkuliahan ini, kami menyampaikan psan bahwa masukan yang objektif akan besar manfaatanya bagi pemenuhan kebutuhan mahasiswa akan bahan ajar yang berkualitas. Hasil bincang kami dengan mahasiswa juga menunjukan bahwa mereka benar-benar mengisi questioner sesuai dengan keadan yang sesungguhnya.

Penilaian secara kuantitatif dan saran yang diberikan oleh mahasiswa mememberikan indikasi bahwa perangkat perkuliahan hasil pengembangan dinantikan kehadirannya, dirasakan manfaatnya, dan memeberikan pengalaman belajar layaknya bagaimana seorang calon guru belajar. Dengan demikian dapat dikatakan bahwa perangkat perkuliahan hasil pengembangan sangat bermanafaat dan tepatguna, serta layak digunakan sebagai bahan ajar bagi mahasiswa pendidikan fisika.

\section{SIMPULAN}

Mengacu pada hasil dan pembahasan yang telah disampaikan, dapat disimpulkan bahwa: (1) Produk yang telah divalidasi oleh teman sejawat pada Program Studi Pendidikan Fisika ini, sudah memenuhi KKNI Program Studi Pendidikan Fisika hasil kesepakatan Asosiasi Pendidikan Fisika Indonesia, yang dibuat berbasis alat pembelajaran fisika abad 21; (2) Semua perangkat perkuliahan yang dihasilkan pada penelitian ini layak digunakan sebagai bahan ajar pada mata kuliah Pengembangan Media Pembelajaran Fisika Berbasis Konteks. 


\section{UCAPAN TERIMA KASIH}

Terima kasih disampaikan kepada Bapak Rektor UNJ dan jajarannya, Bapak Dekan FMIPA UNJ dan jajarannya, serta Bapak ketua Program Studi Pendidikan Fisika yang telah memberikan dukungan moril dan materik, melalui kebijakan pelaksanaan penelitian di lingkungan UNJ.

\section{REFERENSI}

Azzet, A.M. Menjadi Guru Favorit. Yogyakarta: Ar-Ruzz Media, 2011.

Kolb, Alice Y. \& David A. Kolb. Experiential Learning Theory: A Dynamic, Holistic Approach to Management Learning, Education and Development. Cleveland: Case Western Reserve University, 2012.

Mufida, Nur Aini. Pengembangan Bahan Ajar Integratif Fisika Untuk Melatih Keterampilan Berpikir Kreatif Siswa Kelas X SMA. Malang: Universitas Negeri Malang, 2014.

Mulyasa. E. Standar Kompetensi dan Sertifikasi Guru. Bandung : Remaja Rosdakarya, 2007.

Ngoh, Tan Juat. Mastery of The Science Process Skills. Kuala Lumpur: Technical Education Campus, 2009.

Vitti, Debbye \& Angie Torres. Practicing Science Process Skills at Home. 2006.

Yager, R. E. Science/Teaching/Society: As Reform in Science Education. New York: State University of New York Press, 1996.

Zaman, Badru. Media dan Sumber Belajar. Jakarta: Universitas Terbuka, 2007. 